\title{
Feeding the Mechanical Mosasaur: what did Carinodens eat?
}

\author{
A.S. Schulp ${ }^{1,2}$ \\ 1 Natuurhistorisch Museum Maastricht, De Bosquetplein 6, NL-6211 KJ Maastricht, the Netherlands. Email: anne.schulp@maastricht.nl \\ 2 Faculty of Earth and Life Sciences, Vrije Universiteit Amsterdam, the Netherlands.
}

Manuscript received: September 2004; accepted: October 2004

\begin{abstract}
Carinodens is among the smallest known mosasaurs, and one of the most elusive at that. This enigmatic taxon is known from only two dentary fragments and just over a dozen of isolated teeth. Based on this material, an attempt is made to improve our understanding of the dietary habits of this mosasaur, by comparing tooth and jaw morphology to extant analogues, and by testing a biomechanical model with 'feeding' experiments using an artificial mosasaur jaw equipped with a force gauge. Carinodens appears to have been a durophagous mosasaur, capable of crushing small molluscs and arthropods, although its dietary habits may not necessarily have been limited to hard-shelled food.
\end{abstract}

Keywords: biomechanics, Carinodens, Cretaceous, diet, mosasaurs

\section{Introduction}

Mosasaurs were specialised marine reptiles, closely related to snakes and lizards (Bell, 1997; Caldwell, 1999) that went extinct at the end of the Cretaceous. During the last 25 million years of the Cretaceous, these reptiles diversified rapidly to become a highly successful group of marine predators, occupying most of the top predator niches towards the end of the Cretaceous (e.g., Massare, 1997).

Carinodens belgicus is an unusually small mosasaur, at least by latest Cretaceous standards. Its highly specialised tooth morphology suggests that it occupied an ecological niche not exploited by other mosasaurs. In addition to being small and dentally different from other mosasaurs, it is also very rare for reasons yet unknown. To date, the material available consists only of two incomplete dentary fragments, and just over a dozen isolated teeth (Figs. 1, 2); see also Schulp et al. (2004). So far, no postcranial material has been found, or at least no material has been positively identified as such. The stratigraphic distribution of Carinodens in the Maastrichtian type area spans the entire Maastricht Formation (Vonhof \& Smit, 1996;
Jagt et al., 2000; Schulp et al., 2004). Outside the Maastrichtian type area, only three additional occurrences of isolated teeth attributable to Carinodens have been reported: Bulgaria, Morocco, and Brazil. The single tooth crown from Bulgaria (described in Tzankov, 1939, as Globidens fraasi) certainly pertains to Carinodens, although it is slightly smaller than most teeth described from the Maastricht Formation. The material described as Globidens aegyptiacus from Morocco (Arambourg, 1952, pl. 40, fig. 3) could not be located in the collections of the Muséum national d'Histoire Naturelle of Paris (Nathalie Bardet, pers. comm., February 2004), but one of the illustrated teeth is very similar to Carinodens. Some of teeth from Brazil described by Price (1957) are also very similar to Carinodens (Price, 1957, pl. 1, figs. 7 - 9; pl. 2, figs. 1 - 5). The teeth recorded by Avnimelech (1949) as Globidens fraasi from the vicinity of Amman, Jordan, lack the lateral compression characteristic of Carinodens.

Various assumptions have been put forward about the possible dietary preferences of Carinodens (e.g., Dollo, 1913; Lingham-Soliar, 1999). Yet none of these claims were based on actual experiments, or, better still, on preserved stomach 
Fig. 1. a. Map of southern Limburg and adjacent territories, showing localities which have yielded Carinodens material. b. Stratigraphical position of Carinodens occurrences in the type Maastrichtian. Flint levels in black. Lithology after Felder et al. (1978).

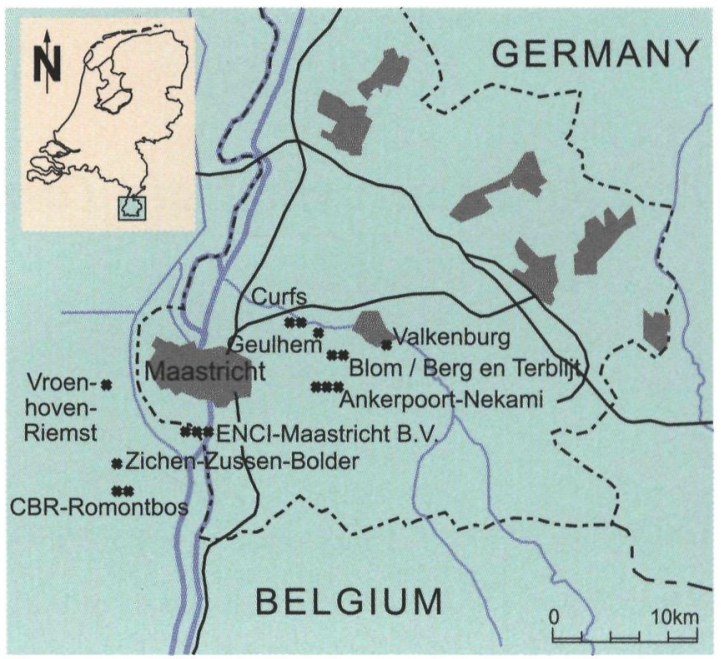

a.

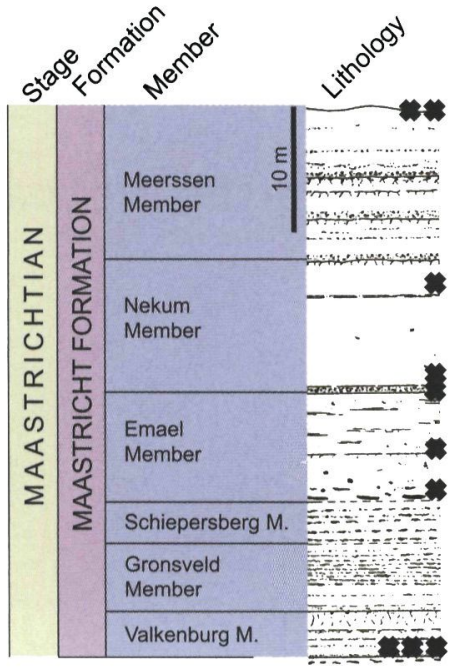

$b$. contents. Instead, the suggested dietary preference was based mainly on general observations and comparisons with the dental morphology of other animals.

The recent discovery of new Carinodens material (Fig. 2A, B) has allowed for a more reliable reconstruction of the mandibular dentition of Carinodens (Fig. 3 and Schulp et al., 2004). Here, this reconstruction will be used to test experimentally some of the proposed dietary habits of Carinodens, in order to have a better idea of the possible prey items that Carinodens could process.

\section{Carinodens diet: earlier ideas}

Carinodens was first described by Dollo (1913), on the basis of a nearly complete right dentary, housed in the Royal Belgian
Institute of Natural Sciences at Brussels, Belgium (IRScNB R43). Dollo initially named the species Globidens fraasi. Kuypers et al. (1998) and Schulp et al. (2004) provided a discussion of the rather complex taxonomic history of the species, now known as Carinodens belgicus.

Gilmore (1912, p. 481), while introducing the genus Globidens, already mentioned the '... peculiar type of dentition that (...) indicate(s) a food habit different from that usually attributed to members of this group.' Gilmore (1912, p. 481) provided an interpretation of possible prey preference: 'The posterior teeth of this form were undoubtedly used only as crushing instruments, and being marine animals it is quite reasonable to suppose their food consisted of shell fish, crustaceans, etc., the harder portions of which were crushed between the bulbous teeth before being swallowed'.

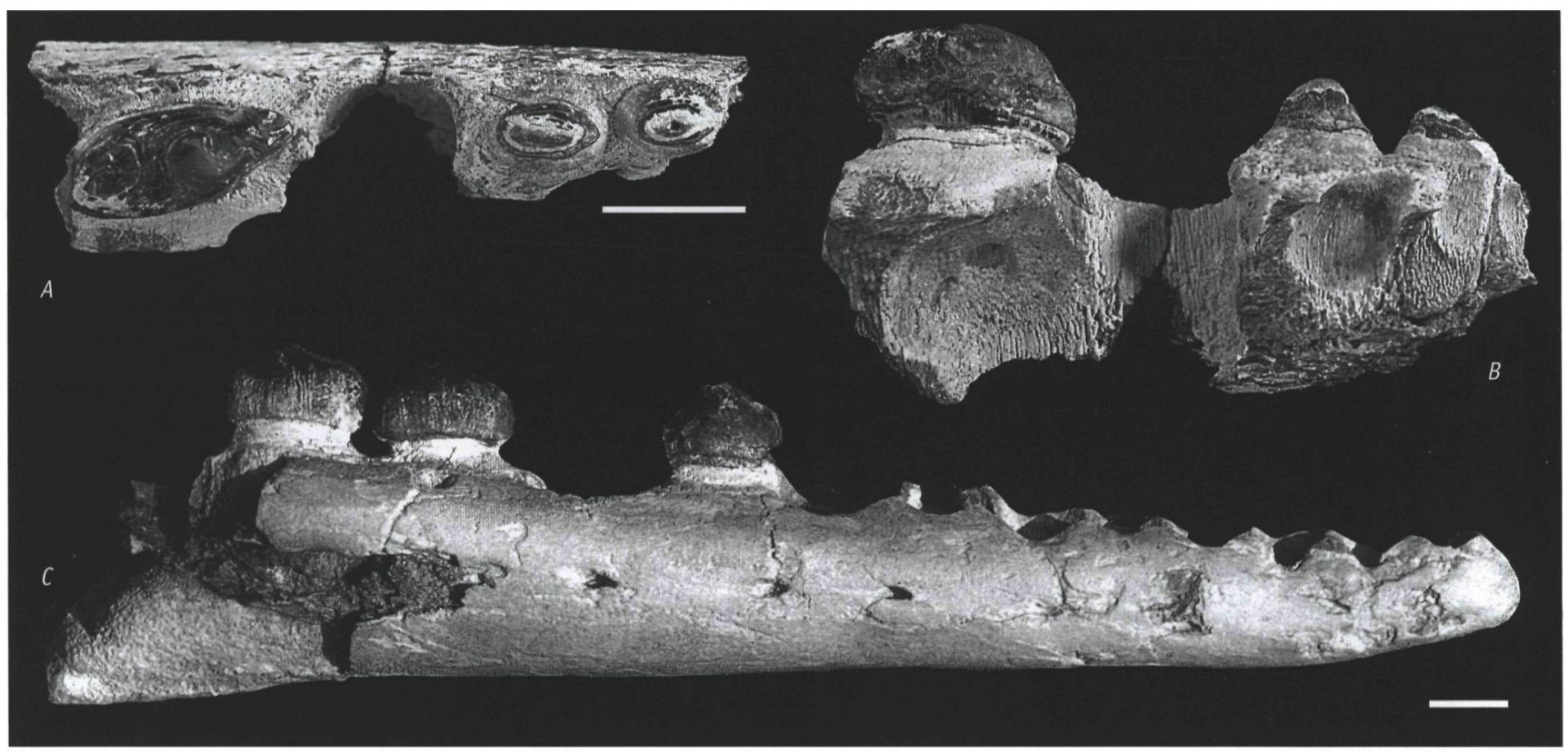

Fig. 2. Carinodens belgicus material. $A, B$ - left dentary fragment of Carinodens belgicus (NHMM2003141) in occlusal (A) and labial (B) view; $C-$ holotype right dentary of Carinodens fraasi (IRSCNB R43) in lateral view. Scale bar $=10 \mathrm{~mm}$. 


\section{Posteriormost dentition:}

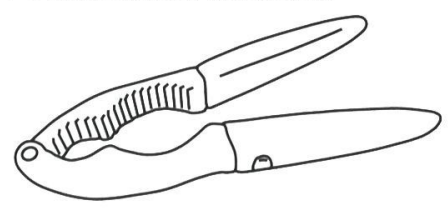

Massive, blunt teeth, close to the hinge:

$20-$

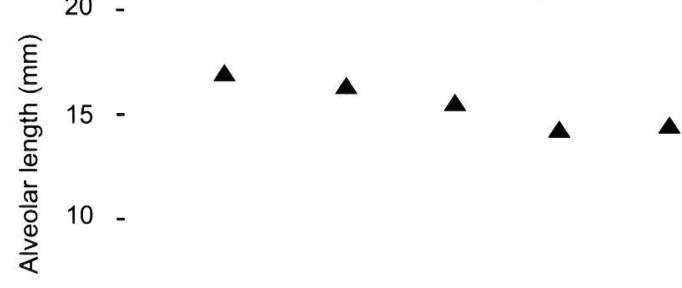

$5-$

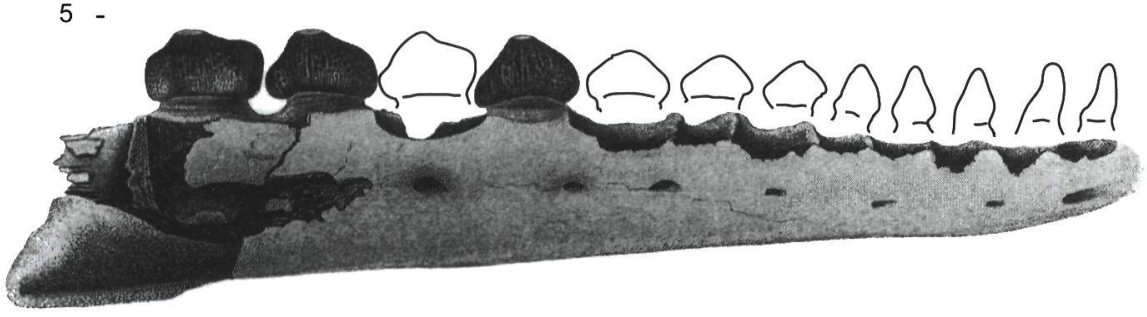

Anteriormost dentition:

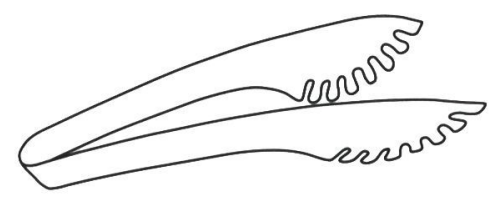

Slender, elongate teeth, far from the hinge: suitable for acquiring and manipulating food
Dollo (1913, p. 618) proposed a subdivision of mosasaurs into three different 'feeding ethology' groups of mosasaurs, based on dental morphology. In addition to the 'régime sarcophage' (meat-eating) and the 'régime teuthophage' (squideating), he introduced a third 'régime'. The 'mylodont' dentition

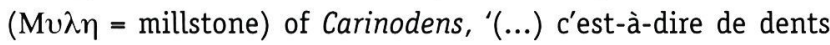
arrondies destinées à broyer', made Dollo list the species in the 'régime durophage' (durophagy). Based on tooth morphology, he listed 1). 'organismes à squelette résistant', such as most molluscs and brachiopods, and 2). 'organismes à squelette fragile', such as most crustaceans and echinoids, as possible prey items. Subsequently, by highlighting the differences in morphology of the dentition with other mollusc-eating reptiles, he considered echinoids to have been the most likely prey items. The relative abundance of echinoderms in the type Maastrichtian, and the presence of an echinoderm fragment preserved between the teeth of the holotype of Carinodens, was seen as support of this interpretation. An interpretation '(...) susceptible de contrôle, si pas immédiat, au moins futur.' (Dollo, 1913, p. 620). However, it seems highly unlikely that the very echinoderm fragment preserved actually represents part of Carinodens diet. A much more plausible explanation would be that the fragment was washed against the jaw after the death of the animal.

Until recently, only a few additional suggestions on the dietary habits of the globidensine mosasaurs have been made since 1913. Dollo (1924) mentioned that Carinodens possessed a 'prehensile' anterior dentition. The illustrated tooth, however, appears to belong to Plioplatecarpus (Kuypers et al., 1998). Antunes (1964, p. 176) suggested a nearshore habitat for
Globidens, but did not add much in terms of possible dietary habits: 'Certamente adaptados a outro tipo de nutrição do que os restantes mosassáurios, os Globidentinae eram possivelmente animais litorais, alimentando-se sobretudo de moluscos, de crustáceos e mesmo de equinídeo, como supôs Dollo (1913, 1925 (=1924)).' The lack of material of 'Globidens' belgicus and fraasi, and the problems involved in comparing them to better known Globidens species was briefly mentioned. Russell (1975) referred to Globidens and Carinodens as a 'group of molluskeating mosasaurs', without discussing the dietary habits in more detail.

As Dollo (1913) did before her, Massare (1987) identified various predatory groups on the basis of tooth morphology, but she presented an overview of all Mesozoic marine reptiles, and proposed seven different feeding 'guilds'. In general, mosasaurs are listed within the 'cut' guild, with the exception of Globidens which is considered a 'crusher'. Carinodens ('Compressidens' in Massare, 1987) was mentioned, but not discussed further.

Lingham-Soliar \& Nolf (1990) and Lingham-Soliar (1999) both listed molluscs (belemnites, Nautilus, bivalves, gastropods, scaphopods), brachiopods, echinoderms, and arthropods as possible food items for Carinodens. Lingham-Soliar (1999, p. 645) considered the '(...) apical cusps on the posterior teeth (...) suited to crushing and shredding the thin shells of invertebrates such as Nautilus and some forms of crustaceans and echinoids rather than piercing.'

Most assumptions cited above are based on observations of tooth morphology only. It should be kept in mind that mosasaurs as a group had a taxonomically diverse appetite. 
Martin (1994) and Martin \& Fox (2004) described a partial skeleton of Globidens containing the remains of small $(4 \mathrm{~cm})$ bivalves. Examples of preserved stomach contents in mosasaurs other than Globidens or Carinodens include fish (e.g., Williston, 1914; Martin \& Bjork, 1987) and birds (e.g., Bjork, 1981). Mulder (2003) linked turtle carapace damage to mosasaur attacks. Kauffman (2004, and references therein) extensively discussed mosasaurs preying upon ammonites and nautiloids. Some mosasaurs attacked or even ate other mosasaurs (Williston, 1898; Martin \& Bjork, 1987; Bell \& Martin, 1995). This wide variety certainly does not help to narrow down the number of possible prey items that Carinodens could have fed upon.

\section{Carinodens jaw}

New material of Carinodens (Schulp et al., 2004; Fig. 2A, B) enables a better reconstruction of the lower jaw. A previous reconstruction of the lower jaw, as proposed by LinghamSoliar (1999) and inspired by the dentition of the savannah monitor lizard Varanus exanthematicus, turns out to be more or less correct.

Most mosasaurs generally are fairly homodont, both in tooth morphology as well as in size; only minor changes in size and shape are observed along the tooth row. This is much less so in Carinodens, as Fig. 3 demonstrates. The anteriormost teeth are apparently relatively small, and fairly slender. The posteriormost five teeth are much more massive, robust and unusually blunt. The change in size between alveolus \#7 and \#8 is rather abrupt. This suggests a functional difference between the anterior- and posteriormost dentition.

The anteriormost dentition (slender, widely-spaced teeth far from the quadrate/glenoid articulation, i.e. far from the 'jaw hinge'), are blunt and not very suitable for cutting prey. The closest functional analogue would be a spaghetti-tong: not designed for processing food, but much better suited to acquisition and manipulation of food (Fig. 3).

The posteriormost dentition (blunt, massive, rounded, closely spaced teeth close to the quadrate/glenoid articulation), is somewhat ribbed, and presumably useless for cutting. The closest functional analogue for these teeth would be a nutcracker: blunt, ribbed 'teeth' providing grip on hard-shelled food. The position close to the hinge provides sufficient leverage to crack hard food, without too much effort (Fig. 3).

These analogues provide support for the proposed durophagous lifestyle of Carinodens, but they preclude specification (or quantification in terms of size) of any group of prey items in particular. Besides that, the dentition might also have been suitable to process soft food to some extent. So what else can jaw and tooth morphology tell about its diet?

Lingham-Soliar (1999) discussed the dental biomechanics of Globidens and Carinodens. The flattening of the teeth (flatter compared to those of most other mosasaurs), resulting in a more dome-shaped tooth morphology, decreases the stresses acting on the tooth, but at the same time the enlargement of the tooth surface in contact with the prey item leads to a decrease in bite pressure. The striae or wrinkles on the teeth of both Globidens and Carinodens are considered to strengthen the tooth, as well as in increasing grip and bite pressure (Lingham-Soliar, 1999 and references therein; see also Peyer (1929) for a discussion of similar adaptations in the tooth morphology of extant squamates).

Although no direct evidence links Carinodens to any particular type of prey, the cross-sectional morphology of the dentary may provide useful information on feeding behaviour. Therrien et al. (2003) and Therrien et al. (in press) presented a biomechanical analysis of the strength of the dentaries of a variety of reptiles. They measured the mandibular (dorsoventral) height and (labiolingual) width of extant and extinct predatory reptiles at three to five locations along the mandible, and modelled the jaw as a simplified solid elliptical beam. The resistance to bending loads during feeding ( $\mathrm{Z}$, section modulus) is correlated to the morphology of the 'beam' and should reflect feeding behaviour: a tall, slender jaw, for example, is strong dorsoventrally and adapted to sustain high biting forces, but is unsuitable for holding struggling prey, as the lateral strength is rather limited.

Mandibular force profiles were designed for Carinodens based on a cast of the holotype, IScRNB R43. The total length of the dentary was estimated from the mandibile of the globidensine mosasaur Prognathodon saturator Dortangs et al., 2002. Comparison of the dentary beam model for Carinodens (Fig. 4) to models of extant varanids provided by Therrien et al. (in press) reveals that Carinodens is more similar to the durophagous, molluscivorous 'Crusher' lizard Varanus niloticus (Nile monitor lizard), than to the 'Slasher' lizard Varanus komodoensis (the 'Komodo dragon' or Ora). In all of these taxa, the dorsoventral as well as the labiolingual strength profile decreases anteriorly at a more or less constant rate, allowing the mandible to be considered as a simple lever (Fig. 4).

The differences in feeding behaviour between the two varanids is clearly represented in the relative mandibular strength profile, expressed as $\mathrm{Zx} / \mathrm{Zy}$ (Fig. 4). Varanus komodoensis has relatively high post-middentary values (superior to 2), indicating that dorsoventral loads are twice as important as the labiolingual loads. $\mathrm{Zx} / \mathrm{Zy}$ values greater than 2 can be linked to better constrained dorsoventral stresses induced by the slicing movement of the jaw. Post-middentary $\mathrm{Zx} / \mathrm{Zy}$ values in $V$. niloticus are much lower (the mandible is much more rounded in cross-section), which resists the relatively larger twisting moments around the long axis induced while cracking hard objects. The mandibular strength profile of Carinodens comes very close to that of the $V$. niloticus.

These similarities support the suggestion that Carinodens was a durophagous mosasaur, but do not shed light on the exact kinds of prey that Carinodens fed upon. If it were feasible to make a well-constrained assumption on the possible bite 
Dorsoventral strength ( $\log Z \mathrm{x} / \mathrm{L})$
Mediolateral strength $(\log Z y / L)$
Relative strength (Zx/Zy)
Fig. 4. Dentaries of $a$. a 'crusher' (Varanus niloticus) and b. a 'slasher' (Varanus komodoensis), compared with $c$. the dentary of the holotype of Carinodens fraasi (IRSCNB R43). Abbreviations and methods: see Therrien et al., in press. Anteriormost $Z x / Z y$ value in Carinodens measured at first alveolus instead of second, because of the presumed short symphyseal length, as suggested by Therrien (pers. comm.); postdentary size estimates based on Prognathodon saturator.

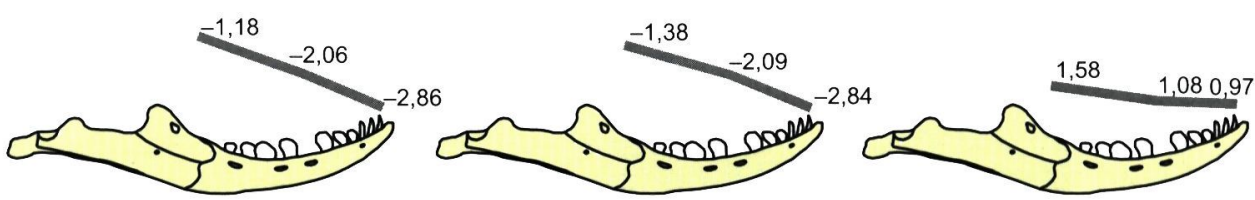

Crusher: Varanus niloticus (mean $L=8,46 \mathrm{~cm}$ )

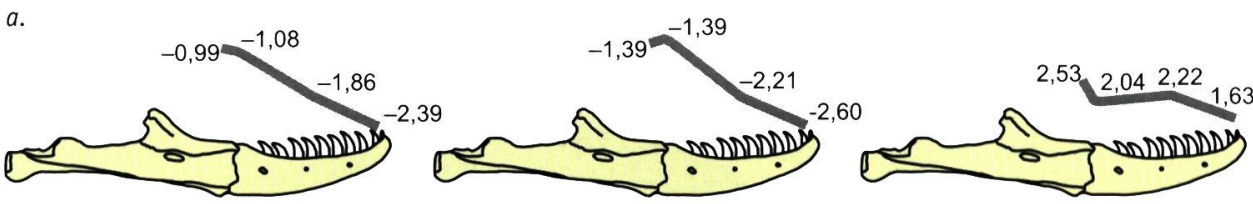

Slasher: Varanus komodoensis (mean $\mathrm{L}=16,96 \mathrm{~cm}$ )

$b$.
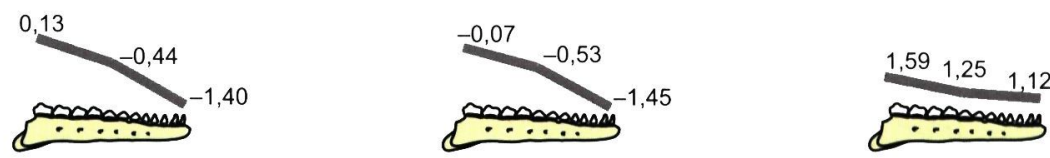

Carinodens belgicus (estimated $\mathrm{L} \approx 28 \mathrm{~cm}$ )

c.

force Carinodens could generate, it would be possible to test some of the previous assumptions. Here, an attempt is made to reconstruct the skull and jaw musculature of Carinodens, followed by an experiment with a 'Mechanical Mosasaur Jaw', which was used to further constrain the possible range of prey items.

\section{Materials and methods}

\section{Skull and musculature reconstruction}

Prior to designing, building and 'feeding' a Mechanical Mosasaur Jaw, an assumption of the maximum bite force is required. Obviously, making assumptions on the bite forces of an extinct animal known by nothing but a lower jaw, is fraught with pitfalls and uncertainties. In order to make a rough estimate of the order of magnitude of the bite force Carinodens could develop, a model of the skull and an assumption on the geometry and the amount of musculature is necessary.

Figure 5 presents an attempt to reconstruct the skull morphology of Carinodens, in which the musculature will be mounted. The dentary is reconstructed following LinghamSoliar (1999) and Schulp et al. (2004).

Very few differences exist between the dentary and maxillary dentition in most reptiles, and this appears to be particularly true in mosasaurs (e.g., Russell, 1967), including Globidens (see Schulp et al., 2004). It seems therefore safe to assume that the maxillary dentition in Carinodens would have been more or less similar to that of the dentary.

The cranium of Carinodens is not known. However, Globidens dakotensis Russell, 1975, is known from a well-preserved skull, housed at the Field Museum of Natural History, Chicago. The outline of this skull is used here as a framework to attach the modelled jaw musculature.

Particularly important in assessing the possible bite force is the relative size of the temporal arcade (Fig. 5). Russell (1975) listed the temporal arcade length / overall skull length ratio as an approximation of the biting power. Globidens dakotensis has a relatively high value of 0.27 . Other globidensine mosasaurs such as Prognathodon overtoni and P. saturator have lower values of about 0.22. For Mosasaurus hoffmanni, also known from Maastricht, Lingham-Soliar (1995) mentioned a value of 0.19. Although this provides the basis for a comparison of the bite force mechanics of different mosasaurs, and although it indicates that Globidens has a relatively strong jaw musculature, it does not provide any absolute data on the forces involved. In the present reconstruction the temporal arcade length / overall skull length ratio of 0.27 is used.

Similarly, the quadrates of all globidensine mosasaurs (Prognathodon, Globidens, and perhaps Carinodens as well) show an adaptation to dealing with greater stresses. The suprastapedial process is fused to the infrastapedial process, making this element, which acted as the jaw hinge, considerably stouter (Russell, 1975; Lingham-Soliar \& Nolf, 1990; Dortangs et al., 2002). Yet another indication of the relatively high bite forces in globidensine mosasaurs is provided by the relatively tall and stout morphology of the dentaries.

The posterior lower jaw unit is not known in Carinodens, nor in Globidens. Therefore, the slightly elongated posterior lower jaw unit of the globidensine Prognathodon saturator Dortangs et al., 2002 is adopted here.

With a tentative bone framework available, the next step is a reconstruction of skull mechanics. In many lizards, the skull consists of an elaborate edifice of independently moveable 


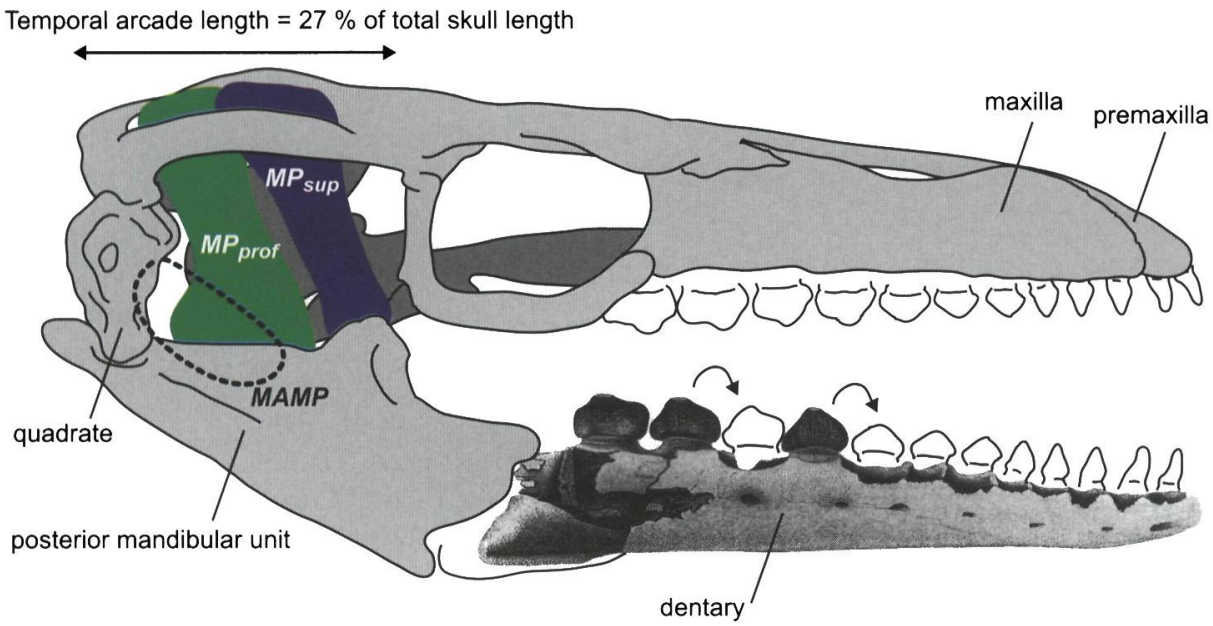

a.

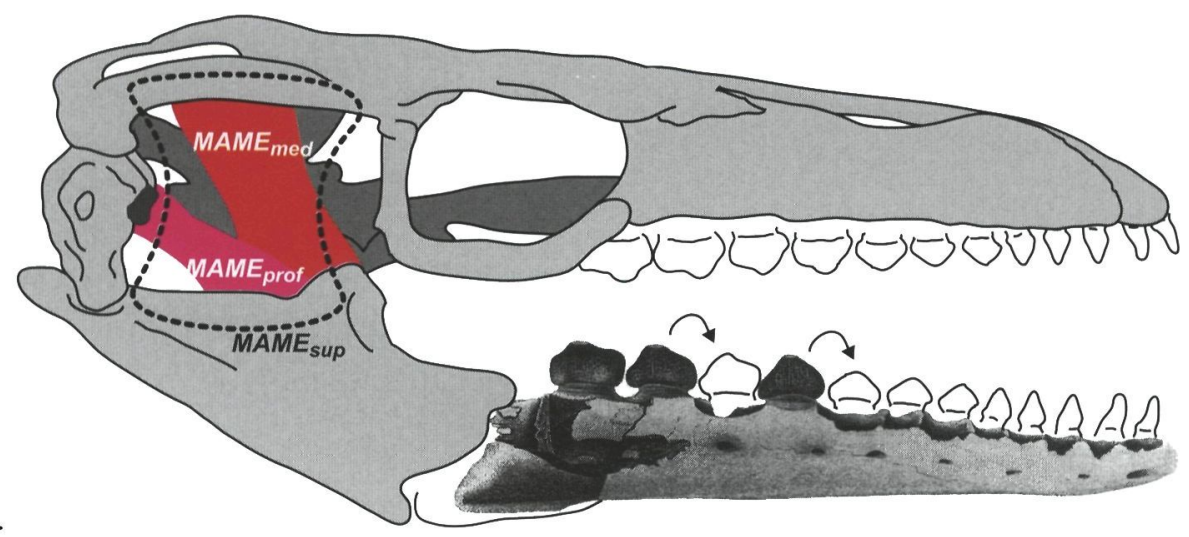

Fig. 5. Attempt to reconstruct the skull and part of the musculature of Carinodens, in order to serve as a basis for a biomechanical model. Carinodens is considered to have been closely related to Globidens. The greater part of the skull is reconstructed based on the holotype (PR 846) of Globidens dakotensis Russell, 1975. The anterior mandibular unit is reconstructed based on IRSCNB R43, NHMM 2003141 (as described in Schulp et al., 2004), and the reconstructed dentary as presented in Lingham-Soliar (1999). The posterior mandibular unit is slightly modified (stretched) from the globidensine mosasaur Prognathodon saturator NHMM 1998141 (Dortangs et al., 2002). The maxillary dentition is mirrored from the reconstructed dentary dentition (see also Schulp et al., 2004). Arrows at the dentary indicate provenance of copied teeth in the mechanical mosasaur (Fig. 7). Estimated skull length ca. $28 \mathrm{~cm}$.

a. Osteological terminology and reconstructed MP and MAMP musculature. b. Reconstructed MAME musculature. Abbreviations of reconstructed musculature: see text. units. Several joints within the cranium allow the maxilla, pterygoid, and other elements of the skull to move more or less independently to some degree (e.g., Metzger, 2002, but see also Herrel et al., 1998a). Russell $(1964,1967)$ discussed this cranial kinesis in mosasaurs in great detail, applying Frazzetta's work (Frazzetta, 1962) on Varanus to mosasaurs. Both Russell (1967) and Lingham-Soliar (1995) noted, however, that at least in 'some later forms (of mosasaurs)' (Russell, 1967, p. 65), this kinesis was lost. The tight sutures in the globidensine Prognathodon saturator clearly did not allow for much movement within the cranium. In the description of Globidens dakotensis, Russell (1975, p. 244) noted that 'the firmly knitted sutures of the cranial elements bordering the mesokinetic axis indicate that it was not functional'.

The lack of cranial kinesis in globidensine mosasaurs allows when modelling Carinodens to regard the cranium as a single, rigid unit, which considerably simplifies the model. Not only can the lower jaw pivot about the quadrate joint, but the quadrate itself can also swing back and forth against the squamosal, a condition referred to as streptostyly (Frazzetta, 1962; Russell, 1964, 1967; Lingham-Soliar, 1995; Metzger, 2002). Lingham-Soliar (1995) mentioned two functions for streptostyly in mosasaurs: in 'ratchet-feeding' (which makes most sense when there are large and / or sharp pterygoid teeth), and as an additional aid in more specialised movements in hardbiting. In Carinodens, these streptostylic (anteroposterior) movements of the lower jaw most likely aided in positioning and 'locking' prey items in place for the subsequent crushing bite. The musculature involved in these anteroposterior movements did not add much to the dorsoventrally directed bite force, and can therefore safely be omitted from consideration in the simplified model presented here.

Three muscle groups are mainly responsible in closing the jaw in most reptiles. Here the main jaw musculature is reconstructed following Russell $(1964,1967)$, Sinclair \& Alexander (1987) and Lingham-Soliar (1995). Reference is also made to Herrel et al. (1998b), for a discussion of modelling in extant lizards.

The $M$. adductor mandibulae externus group (MAME), originating on the postorbitofrontal, squamosal and lateral surface of the quadrate, inserts on the lateral surface of the coronoid and the surangular. In mosasaurs (and in many other reptiles, as well), these muscles appear to have been the most important in closing the jaw.

M. pseudotemporalis (MP), divided into M. pseudotemporalis superficialis and M. pseudotemporalis profundus are located deeper. M. pseudotemporalis superficialis originates from the lateral surface of the parietal and inserts in the coronoid apex, 
M. pseudotemporalis profundus is attached to the braincase and inserts in the medial surfaces of the surangular and prearticular.

M. adductor mandibulae posterior (MAMP) acts between the medial surface of the coronoid and the quadrate (Russell, 1964; this muscle is not mentioned in the reconstruction by LinghamSoliar, 1995). M. adductor mandibulae externus profundus also attaches to the quadrate, but more externally, next to $M$. adductor mandibulae posterior.

Not considered in the model described here, as its relative importance in the bite force appears limited, is M. pterygoideus. This muscle acts more or less anteriorly, and while contracting it mainly pulls the jaw forward. It also helps to counteract the medial rotation of the dorsal margin of the lower jaw, exerted by the predominantly inward-directed adductor musculature (e.g., Lingham-Soliar, 1995).

The cross-sectional areas of the three major muscle groups were graphically determined on the dorsal view of a scaled image of the skull of Globidens dakotensis. A reasonable estimate of the force a muscle of a given cross-sectional area can exert would correspond to some $300 \mathrm{kPa}$ (Sinclair \& Alexander, 1987). The MAME-complex, with a cross-sectional area of about $7 \mathrm{~cm}^{2}$, could exert a maximum force of $210 \mathrm{~N}$. Similarly, the $9 \mathrm{~cm}^{2} \mathrm{MP}$ yields $270 \mathrm{~N}$, and the $3 \mathrm{~cm}^{2}$ MAMP could perhaps exert a force of $90 \mathrm{~N}$.

Using the estimated maximum muscle forces, the maximum unilateral bite force on each tooth can be calculated. Only MAME, MP and MAMP are considered in this model. From the model, it is obvious that bite force will decrease with wider gape angles (see e.g., Dumont \& Herrel, 2003). Here, the maximum bite force is calculated with a low gape angle, corresponding to a prey item of only $15 \mathrm{~mm}$, locked between the posteriormost teeth.

In a simplified model (Fig 5), the force vectors $\Sigma F_{\text {MAME, }}$ $\Sigma F_{\text {MP }}$ and $\Sigma F_{\text {MAMP }}$ act on the jaw under angle $\alpha, \beta$ and $\gamma$, respectively. The resulting torque $\Sigma M$ is calculated by multiplying the force with the length of the arm and the sine of the angle of the action while holding a $15 \mathrm{~mm}$ 'prey' item. The maximum bite force at every tooth can be calculated by dividing
$\Sigma M$ by the distance of the tooth to the hinge. The angles $\alpha$ through $\gamma$ were graphically determined from the proposed average muscle configuration in Fig 5, which yielded an estimated bite force at the posteriormost tooth $F_{\text {tooth12 }}$ of $231 \mathrm{~N}$ (Fig. 6).

It should be noted that only static bite experiments are considered here. Impact biting, where the impact of the teeth is increased because of the inertia of the closing jaws (e.g., Sinclair \& Alexander, 1987), or even the entire 'head-banging' skull slashing into the prey (e.g., Rayfield et al., 2001; Erickson, 2001), would not have dramatically increased the effectiveness of the bite of Carinodens. Larger animals and heavier skulls are required for such a purpose.

Although biting biomechanics is essentially a 3-dimensional problem, only unilateral biting in a 2-dimensional plane is considered here. Dumont \& Herrel (2003) assume the unilateral bite force to represent half of the bilateral bite force value, but in many cases this might represent a slight underestimate, as the opposite jaw may also contribute to the bite force. However, in mosasaurs the dentaries were only loosely connected at the symphyseal area, so it appears safe to assume that the opposite jaw contributed only very little to the bite force.

In summary, based on the considerations above, it appears likely that the maximum unilateral bite force Carinodens could reach between the posteriormost teeth, would have been a few hundreds of Newtons. Bite forces above $500 \mathrm{~N}$ appear very unlikely. More cranial material and a more elaborate biomechanical model is obviously needed to increase its accuracy; for now, this crude estimate will be used to constrain experimentally the possible prey items of Carinodens.

\section{The Mechanical Mosasaur}

Based on the skull reconstruction discussed in the previous section, and the proposed maximum bite force, a simple mechanical jaw model was built.

First, a (second-generation) mould was produced of the dentition of the cast of IRSCNB R43 in the NHMM collections,

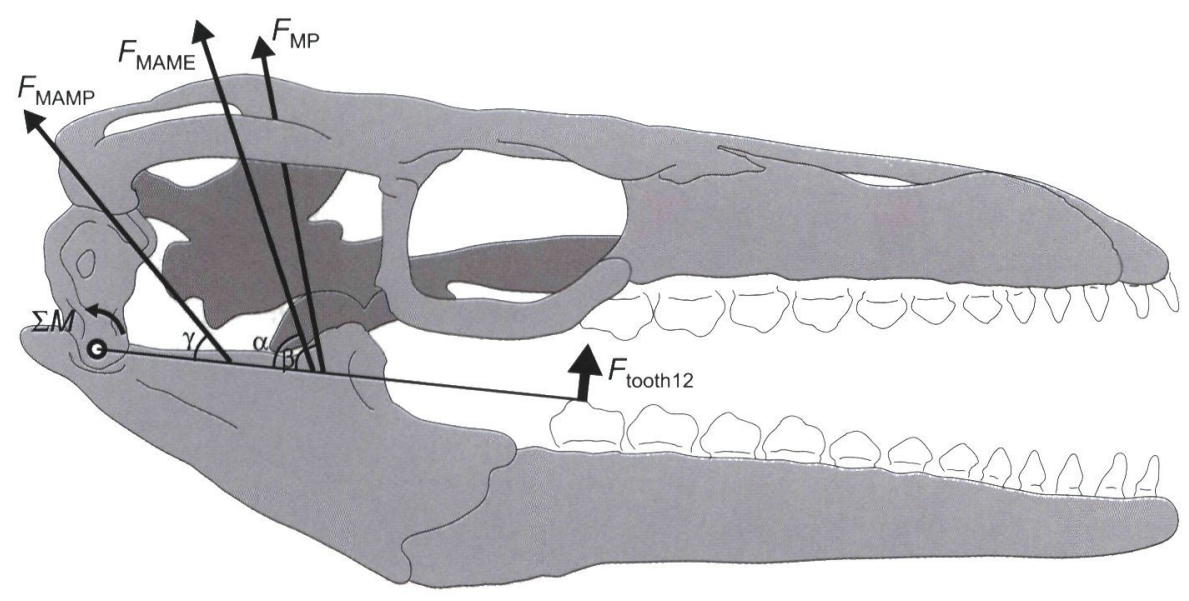

Fig. 6. Simplified biomechanical model of Carinodens belgicus. 
using silicone rubber. In the holotype, teeth \#9, \#11 and \#12 are preserved. The eleventh and ninth tooth were moulded and cast, and the casts were subsequently mounted (using plasticine clay) in the dentary in positions \#10 and \#8, respectively (see Fig. 3 ). The resulting 'full' posterior dentition, spanning alveoli 8 through 12 , was subsequently moulded in silicone rubber. Using this mould, two casts were produced, using an extremely tough variety of polyurethane resin, 'Smooth-Cast 70D'. For plastics, the hardness is generally expressed in 'Shore hardness', a hardness scale expressing the resistance of material to indentation on a scale from 0 to 100 (according to IS0 test method 868). The Shore A scale is used for soft plastics, while the Shore D scale is designed for harder ones. The PU-resin used here has a score of 70 on the Shore D scale (data provided by the distributor, AFF Materials in Amsterdam), which is roughly similar to brass, the material initially considered for this experiment. A direct comparison with dentine is a bit difficult, as the hardness of dentine is not generally expressed in Shore numbers. However, considering that brass is slightly softer than dentine (following the Mohs hardness scale), we can assume that the teeth used in this experiment were slightly too soft, perhaps resulting in a somewhat less effective shattering of very brittle materials. The alternative, using teeth copied in steel (as done by Abler, 1992), would have required high-resolution 3D-scanning and CNC-machining instead of simple moulding and casting, which would have increased the project cost by several orders of magnitude.

The two polyurethane jaw elements were subsequently attached to two flat pieces of wood using 2-component polyurethane glue. These wooden supports were attached (using M4 bolts and nuts) to one-metre long aluminium ' $u$ '-profiles, each with external dimensions of $20 \times 20 \mathrm{~mm}$, and $2 \mathrm{~mm}$ thick.

The aluminium strips were mounted in a framework as illustrated in Fig. 7. Hinges were made using $15 \times 15 \mathrm{~mm}$ aluminium ' $u$ '-profiles and stainless-steel M6 bolts and nuts. Two additional $15 \times 15 \mathrm{~mm}$ aluminium ' $\mathrm{u}$ '-profiles act as a guiding rod to keep the upper and lower 'jaw' aligned. The position of the hinge and the dentition corresponds to the model proposed in Fig. 4.

A mechanical force gauge (no brand name, 'Made in Germany', $\max .25 \mathrm{~kg}$ ) from a local hardware store was used to measure the 'bite' force which was manually applied by pulling a string looped through a pulley with the force gauge (Fig. 7). More sophisticated electronic force gauges do provide more accuracy and a convenient readout in $\mathrm{N}$ instead of $\mathrm{kgs}$, but this would significantly increase construction complexity and cost, and the improvement in precision is not at all necessary, considering the uncertainties surrounding the assumptions on jaw musculature.

A variety of possible prey analogues was acquired fresh at the Friday fish market in Maastricht, on February 13 and 27, 2004. Sea urchins, temporarily unavailable in Maastricht, were

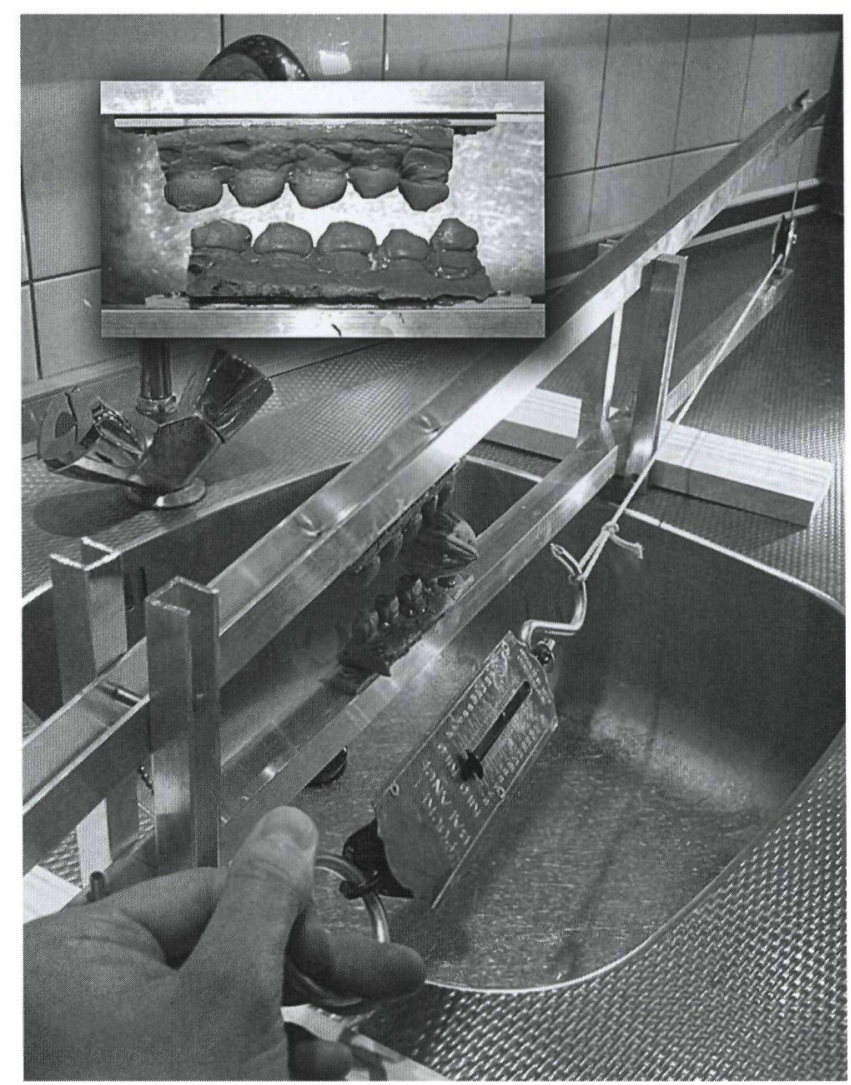

Fig. 7. The Mechanical Mosasaur. Inset: close-up of cast dentition.

acquired in Brussels on March 10, 2004. All identifications of the seafood purchased were verified using Davidson (1972, 1979). The same sources also provided helpful suggestions in processing material left over after the experiment.

The Mechanical Mosasaur Jaw was installed above a kitchen sink, and biting experiments were performed, each time measuring dimensions of the 'prey' item, the thickness of its shell and the force required to break it. Initial breaking was performed using the posteriormost teeth only, but depending on the shape of the prey item, sometimes additional teeth participated in holding prey. Measurements were performed with as few teeth as possible touching the shell in order to obtain maximum pressure.

'Chewing' experiments, to have an idea of further oral processing capabilities of Carinodens, were performed using all five posteriormost teeth in the model.

The force at the lever (in $\mathrm{N}$ ) was calculated by multiplying the readings from the force gauge (in this case in $\mathrm{kg}$ ) by 9.8 (the gravitational acceleration $g ; 9.8 \mathrm{~ms}^{-2}$ at the Earth's surface) in order to obtain the force. The attachment of the rope to the jaw lever and the pulley are both at $900 \mathrm{~mm}$ from the hinge, while the posteriormost tooth is at $142 \mathrm{~mm}$ from the hinge, hence forces at the tooth were calculated by multiplying the force read by $(900 / 142)$, and adding $5.4 \mathrm{~N}$ to the result because of the weight of the lever itself. Without too much effort, bite forces of up to $1,000 \mathrm{~N}$ on the posteriormost teeth were attained. 
As the model proposed here involves a considerable number of uncertainties, and it is developed only to acquire an idea of the order of magnitude of likely bite forces, it is stressed again that all results presented here should be considered with caution.
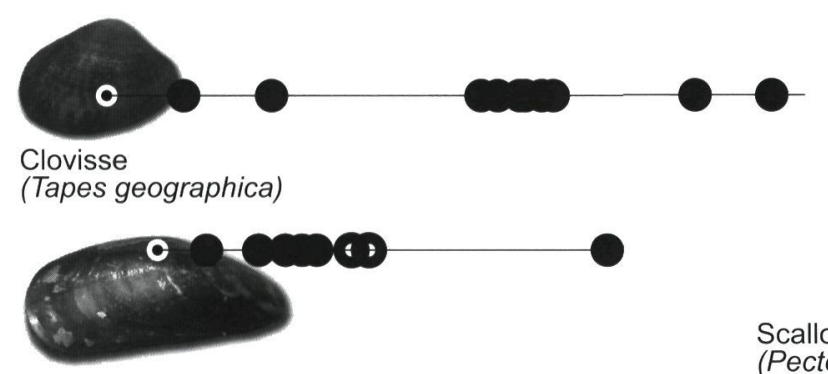

Musse (Mytilus edulis)

\section{Results}

The results of the experiment are graphically summarised in Fig. 8. Small shrimps (such as Parapenaeus longirostris), with an exoskeleton of a few tenths of millimetres thick only, were
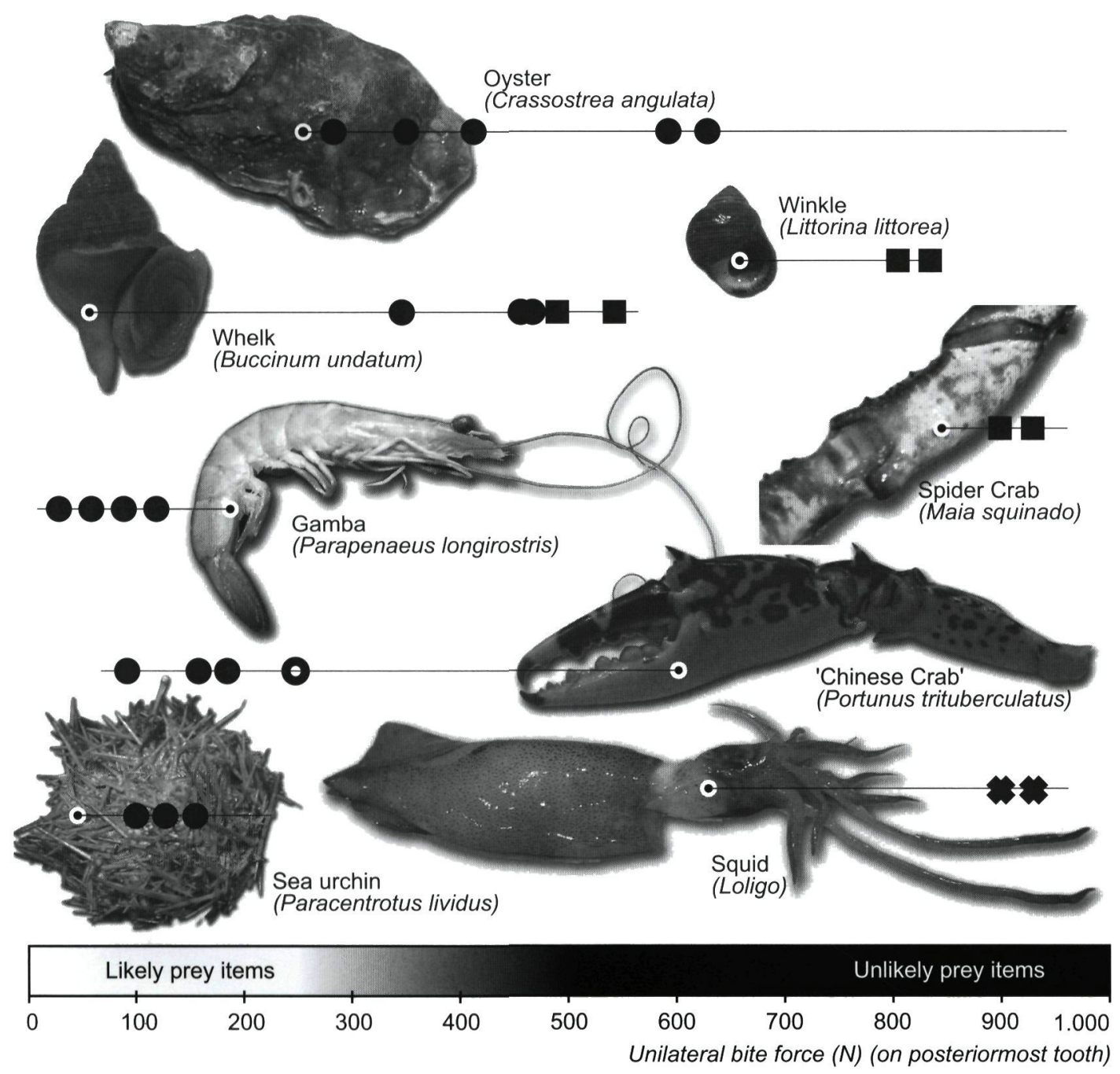

\footnotetext{
- Labrador (Canis domesticus) Orang utan (Pongo pygmaeus)

- Flying fox (Pteropus vampyrus)

- Wolf (Canis lupus)
}

- Human (Homo sapiens)

Fig. 8. Prey items fed to the Mechanical Mosasaur. Solid squares: maximum force reached during failed attempt - 'prey' detached or end of scale reached. Solid circles: force required for successful crushings. Open circles: force required for additional breaks after first successful crushing attempt. Crosses: meat cutting failed. Bite force data on extant animals are listed below for comparison; data from Erickson et al. (1996) and Dumont \& Herrel (2003), with unilateral bite force $=0,5$. bilateral bite force value, which might represent a slight underestimate (Dumont \& Herrel, 2003). 
easily processed at any position on the posterior dentition. Forces required should have been well within the capabilities of Carinodens.

This is much less so with thicker-shelled prey such as 100 to $130 \mathrm{~mm}$ wide scallops, or Coquilles Saint-Jacques (Pecten maximus), or thick-shelled, $\sim 25 \mathrm{~mm}$ tall globose gastropods such as Winkles (Littorina littorea). Some attempts to break the shell of these animals failed even at more than three times the suggested maximum bite force of Carinodens. However, by strategically reshuffling the Pecten shells such that only one pair of teeth had grip near the rim of shell, some attempts to crush small $(100 \mathrm{~mm})$ Pecten shells did lead to breakage, after which further processing became considerably easier. Larger Pecten shells must have been beyond the capabilities of Carinodens. Small oysters, such as the 84 to $117 \mathrm{~mm}$ long Crassostrea angulata all required bite forces near the proposed maximum bite force.

Smaller bivalves, such as 31 to $42 \mathrm{~mm}$ large Clovisses (Tapes geographica), must have been well within reach of Carinodens. With shell thicknesses ranging from about 0.9 to $1.4 \mathrm{~mm}$, all shells (sometimes after a few attempts) were successfully crushed within the likely range of bite force. The same is true for Mussels (Mytilus edulis, lengths of 55 to $62 \mathrm{~mm}$ ). Whelks (Buccinum undatum), ranging in size from 60 to $88 \mathrm{~mm}$ were relatively easily crushed as well, despite the fact that their shells are often relatively thick (more than a few $\mathrm{mm}$ ).
Attempts to process squid meat (Loligo) between the posteriormost dentition completely failed. The teeth are clearly insufficiently sharp to cut the rubbery squid flesh.

Several attempts to crush various parts of a Spider Crab (Maia squinado; maximum carapace dimensions $\sim 200 \mathrm{~mm}$ ) all remained unsuccessful. In contrast, the apparently similarly sized and thick-shelled 'Chinese crab'-claws (Portunus trituberculatus) were relatively easily crushed. The fact that these claws were relatively wider and somewhat flattened compared to Maia squinado, hence less mechanically stable, probably explains the difference.

Sea urchins such as Paracentrotus lividus (52 to $67 \mathrm{~mm}$ diameter) were crushed without much effort: none of the attempts required more than $150 \mathrm{~N}$ of bite force.

\section{Discussion}

Small arthropods, bivalves smaller than $100 \mathrm{~mm}$ with shells thinner than approximately $1.5 \mathrm{~mm}$, and small gastropods would certainly have been within the ability of Carinodens to crush. Large oysters, or thick-shelled food which just did not provide sufficient grip, such as the fairly common gastropod Otostoma retzii, were probably beyond reach.

Although the dentition of Carinodens proves to be an efficient tool for crushing extant molluscs, some gastropods provided difficulties while performing the experiment. Most attempts to crush the massive, rather smooth-surfaced Winkles

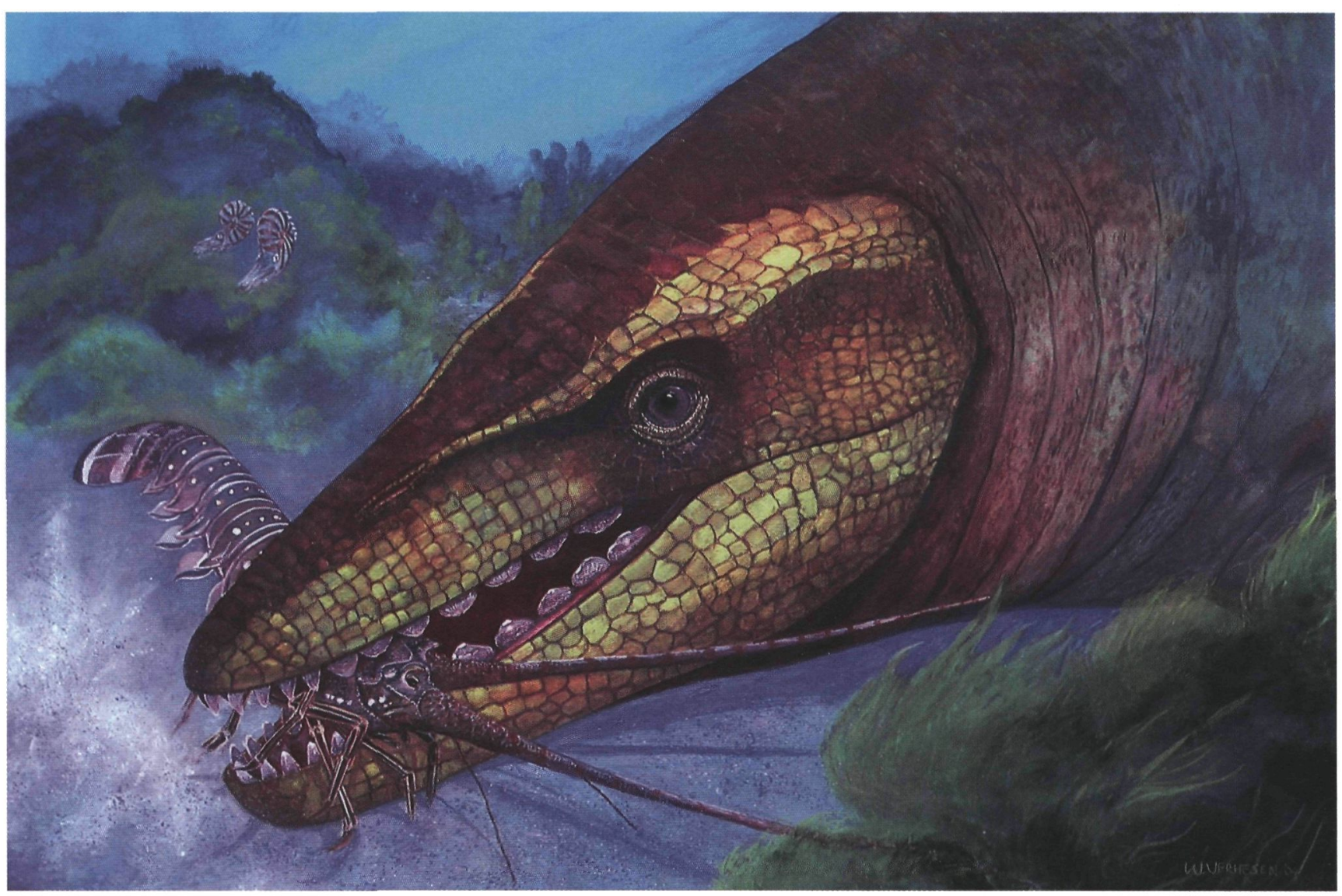

Fig. 9. Restoration of Carinodens. Artwork by Wouter Verhesen. 
(Littorina littorea) failed because the shell jumped away from between the teeth when force was applied. In those attempts where the shell did lock between the teeth, the shell did not break until the higher end of the force gauge scale was reached. Perhaps some degree of oral processing involving manipulation with the tongue would have provided a live Carinodens with an advantage absent in the experiment, but some differences in frictional surface properties between tooth enamel and polyurethane cannot be ruled out either. Whelks on the other hand, although larger and thicker, offered sufficient grip to the teeth of Carinodens.

The unusual dentition did tempt Dollo $(1913,1924)$ and Lingham-Soliar \& Nolf (1990) to link Carinodens to a durophagous lifestyle. However, the compressed, somewhat pointed teeth still do allow to process certain types of softer food quite well, as the experiments (e.g., with gambas such as Parapenaeus longirostris) have shown. Therefore, there is no reason to assume that Carinodens, notwithstanding its specialised dentition, did not fancy soft food.

If Carinodens ate cephalopods such as ammonites, the relatively thin shell would not have offered great protection against this predator. Experiments suggest, however, that the dentition of Carinodens was poorly suited for oral processing of the rubbery squid meat, which leaves only smaller squid (small enough to be swallowed whole) as possible prey. Larger ammonites probably were not on the menu. Similarly, this suggests that Carinodens did not eat large belemnites either.

Sea urchins, at least those whose spine size did not dissuade Carinodens from attacking, must have been an easy prey for this mosasaur. So far, no evidence of Carinodens bite marks on sea urchins from the Maastricht area has ever been identified, but this is hardly surprising, given the fact that the bite of a mosasaur even in case of a failed attack would have shattered the test of the urchin rather than leaving behind bite marks. This observation is supported by the study by Kowalewski \& Nebelsick (2003, p. 287), who discussed predation on Recent and fossil echinoids: 'because sea otters smash completely the test of their prey while feeding, it is highly unlikely that the predation by sea otters can be recognized in the fossil record of echinoids'.

Mosasaurs (and most other reptiles) had to depend exclusively on their jaws in handling their prey. The short flippers were of little use in manipulating food. Being marine animals, they had to rely entirely on the inertia and drag of the floating or submerged prey items, and on the dexterity of their jaws and tongue. The pterygoid dentition, used in so-called 'ratchetfeeding' (e.g., Lingham-Soliar, 1995) was considerably reduced in Globidens. Apparently these more specialised globidensine mosasaurs did quite well without a functional pterygoid dentition, as recurved teeth in the pterygoid are considered especially useful in dealing with large, fleshy, struggling prey.

During the experiments, the polyurethane surface of the dentition developed wear marks. The position of the wear is very similar to the wear observed in Carinodens, confirming again that the wear pattern in fossils most likely developed during life, and not as a result of taphonomic processes. This also lends additional support to close the gap between the 'fresh', somewhat tricuspid teeth which have been described as $C$. belgicus, and the probably more abraded teeth that have been described as C. fraasi, as discussed in Meijer (1982). Carinodens fraasi is no longer considered valid, as it is a junior synonym of $C$. belgicus (Kuypers et al., 1998).

One question remains. Why are all isolated Carinodens teeth that have been recognised so far posterior teeth? One would expect at least a few anterior teeth to have been identified, as over a dozen posterior teeth have been reported so far. The worn-down, rather featureless character of the anterior teeth preserved in NHMM2003141, combined with the lack of awareness among local fossil collectors to properly recognise these fossils appear a very likely explanation for the fact that no isolated anterior Carinodens teeth have yet been reported. Additionally, thinner enamel, related to the fact that these teeth probably were not involved in crushing the hard-shelled prey, may have reduced the chance of fossilisation of these teeth.

The rarity of Carinodens in the fossil record still remains unexplained. Because of the relatively small size of this mosasaur, an underrepresentation in the fossil record comes as no surprise. A collecting bias preferring larger mosasaur teeth cannot be ruled out either. Still, this does not explain why, after 250 years of intensive collecting in the Maastricht area, Carinodens still is known only from a dozen teeth and two jaw fragments only.

It is interesting to note that Globidens, a larger durophagous mosasaur which enjoyed a wide geographic distribution, has never been reported from the Maastrichtian type area. A detailed study of the faunal composition of the palaeoenvironments of Globidens and Carinodens could perhaps shed more light on this absence, and, combined with a similar study with a mechanical mosasaur jaw for Globidens, may indicate that the two durophagous taxa may have competed in their prey preferences, although they were of considerably different size. Perhaps a better understanding of the ecology, food and habitat preferences of Carinodens could also yield answers to explain the rarity of this mosasaur in the fossil record.

\section{Conclusions}

A biomechanical estimate of the bite force of Carinodens, applied to a mechanical jaw model provides a constraint on the possible prey items this mosasaur could have processed. Echinoids, smaller bivalves, and gastropods are considered to have been likely prey items. Carinodens was probably less successful in crushing larger bivalves such as scallops and oysters which exceeded $100 \mathrm{~mm}$ in size. Particularly rounded gastropods, such as winkles, may not have provided sufficient 
grip to be crushed. The proposed feeding preference on various kinds of squid is questioned here. The rubbery meat, combined with the poor cutting properties of the teeth probably provided some difficulties for Carinodens in processing larger squid. Smaller squid, which did not require much oral processing beyond crushing a shell (if present), could have been easily swallowed whole. The fact that the dentition of Carinodens was well adapted to crushing hard-shelled prey does not imply that it did not eat softer food. Animals such as shrimp are quite easily processed, so there is no reason to exclude such animals a priori from the menu.

\section{Acknowledgements}

Technical support by Aart Walen (Creatures \& Features, Doornenburg) was invaluable while modelling, moulding and casting Carinodens teeth. John Jagt, Douwe de Graaf, Fokeline Dingemans, Eric Mulder, Hanneke Meijer, David Weishampel and Donald Henderson provided helpful suggestions and feedback on the manuscript in various review stages. Thanks to Ruud Dortangs, who took the photographs of Fig. 2. Thanks to Frans Fonken and all the other collectors who recently discovered additional material of Carinodens, and share their material with the NHMM. François Therrien provided helpful feedback on the strength profiles of the jaw. Thanks to Wouter Verhesen for drawing the life restoration of Carinodens.

\section{References}

Abler, W.L., 1992. The serrated teeth of tyrannosaurid dinosaurs, and biting structures in other animals. Paleobiology 18: 161-183.

Antunes, M.T., 1964. 0 Neocretácico e o Cenozóico do Litoral de Angola. Junta de Investigaçōes do Ultramar (Lisbon): $255 \mathrm{pp}$.

Arambourg, C., 1952. Les vertébrés fossiles des gisements de phosphates (MarocAlgérie-Tunisie). Notes et Mémoires du Service géologique du Maroc 92: 1-372.

Avnimelech, M., 1949. On Vertebrate Remains in Senonian Phosphate Beds in Transjordan. Eclogae geologicae Helvetiae 42: 486-490.

Bell, G.L. Jr., 1997. Mosasauridae. Introduction. In: Callaway, J.M. \& Nicholls, E.L. (eds): Ancient Marine Reptiles. Academic Press (New York/London): 281-292.

Bell, G.L. Jr. \& Martin, J.E., 1995. Direct evidence of aggressive intraspecific competition in Mosasaurus conodon (Mosasauridae: Squamata). Journal of Vertebrate Paleontology 15 (suppl. to 3): 18A.

Bjork, P.R., 1981. Food habits of mosasaurs from the Pierre Shale of South Dakota. Geological Society of America Abstracts with Program 13: 191 (Rocky Mountains Section, Rapid City, SD).

Caldwell, M.W., 1999. Squamate phylogeny and the relationships of snakes and mosasauroids. Zoological Journal of the Linnean Society 125: 115-147.

Davidson, A., 1972. Mediterranean Seafood. Penguin (London): 425 pp.

Davidson, A., 1979. North Atlantic Seafood. Macmillan (London): 512 pp.

Dollo, L., 1913. Globidens Fraasi, mosasaurien mylodonte nouveau du Maestrichtien (Crétacé supérieur) du Limbourg, et l'Ethologie de la Nutrition chez les Mosasauriens. Archives de Biologie 28: 609-626.
Dollo, L., 1924. Globidens alabamaensis, Mosasaurien mylodonte américain retrouvé dans le Craie d’Obourg (Sénonien supérieur) du Hainaut, et les Mosasauriens de la Belgique, en général. Archives de Biologie 34: 167-213.

Dortangs, R.W., Schulp, A.S., Mulder, E.W.A., Jagt, J.W.M., Peeters, H.H.G. \& de Graaf, D.Th., 2002. A large new mosasaur from the Upper Cretaceous of the Netherlands. Netherlands Journal of Geosciences 81: 1-8.

Dumont, E.R. \& Herrel, A., 2003. The effect of gape angle and bite point on bite force in bats. The Journal of Experimental Biology 206: 2117-2123.

Erickson, G.M., 2001. The bite of Allosaurus. Nature 409: 987-988.

Erickson, G.M., Van Kirk, S.D., Su, J., Levenston, M.E., Caler, W.E. \& Carter, D.R., 1996. Bite-force estimation for Tyrannosaurus rex from tooth-marked bones. Nature 382: 706-708.

Felder, W.M., Felder, P.J., Kuyl, O.S., Van Amerom, H.W.J., Bosch, P.W. \& Meessen, J.P.M.T., 1978. Paläontologische Gesellschaft-Palaeontological Association, Joint Annual Meeting, Maastricht 25.10.1978, Excursion G. Lithology and stratigraphy of the Maastrichtian and Dano/Montian chalk in the type area on both sides of the River Maas, pp. 65-94. Maastricht.

Frazzetta, T.H., 1962. A functional consideration of cranial kinesis in lizards. Journal of Morphology 111: 287-319.

Gilmore, C.W., 1912. A new Mosasauroid reptile from the Cretaceous of Alabama. Proceedings of the Unites States National Museum 41: 479-484.

Herrel, A., Aerts, P., \& De Vree, F., 1998a. Ecomorphology of the lizard feeding apparatus: a modelling approach. Netherlands Journal of Zoology 48: 1-25.

Herrel, A., Aerts, P., \& De Vree, F., 1998b. Static biting in lizards: functional morphology of the temporal ligaments. Journal of the Zoological Society of London 244: 135-143.

Jagt, J.W.M., Dortangs, R.W. \& Mulder, E.W.A., 2000. First appearance of the mosasaur Carinodens belgicus (Woodward, 1891) in the type Maastrichtian. Fifth European Workshop on Vertebrate Paleontology, Karlsruhe (Abstracts): 37.

Kauffman, E.G., 2004. Mosasaur Predation on Upper Cretaceous Nautiloids and Ammonites from the United States Pacific Coast. Palaios 19: 96-100.

Kowalewski, M. \& Nebelsick, J.H., 2003. Predation on Recent and Fossil Echinoids. In: Kelley, P.H., Kowalewski, M. \& Hansen, T.A. (eds): PredatorPrey Interactions in the Fossil record (Kluwer Academic / Plenum Publishers, New York): 279-302.

Kuypers, M.M.M., Jagt, J.W.M., Peeters, H.H.G. \& de Graaf, D.Th., 1998. Laatkretaceische mosasauriers uit Luik-Limburg: nieuwe vondsten leiden tot nieuwe inzichten. Publicaties van het Natuurhistorisch Genootschap in Limburg 41: 5-48.

Lingham-Soliar, T., 1995. Anatomy and functional morphology of the largest marine reptile known, Mosasaurus hoffmanni (Mosasauridae, Reptilia) from the Upper Cretaceous, Upper Maastrichtian of the Netherlands. Philosophical Transactions of the Royal Society of London. B 347: 155-180.

Lingham-Soliar, T., 1999. The Durophagous Mosasaurs (Lepidosauromorpha, Squamata) Globidens and Carinodens from the Upper Cretaceous of Belgium and the Netherlands. Paleontological Journal 33: 638-647.

Lingham-Soliar, T. \& Nolf, D., 1990. The mosasaur Prognathodon (Reptilia: Mosasauridae) from the Upper Cretaceous of Belgium. Bulletin de l'Institut Royal des Sciences Naturelles de Belgique, Sciences de la Terre 59 (1989): 137-190.

Martin, J.E., 1994. Gastric residues in marine reptiles from the Late Cretaceous Pierre Shale in South Dakota: their bearing on extinction. Journal of Vertebrate Paleontology 14(suppl. to 3): 36A. 
Martin, J.E. \& Bjork, P.R., 1987. Gastric residues associated with a mosasaur from the Late Cretaceous (Campanian) Pierre Shale in South Dakota. In: Martin, J.E., Ostrander, G.E. (eds): Papers in Vertebrate Paleontology in honor of Morton Green. Dakoterra 3: 68-72.

Martin, J.E. \& Fox, J.E., 2004. Molluscs in the stomach contents of Globidens, a shell crushing mosasaur, from the Late Cretaceous Pierre Shale, Big Bend area of the Missouri River, central South Dakota. Geological Society of America, 2004 Rocky Mountain and Cordilleran Regions Joint Meeting, Abstracts with Programs, 36(4): 80.

Massare, J.A., 1987. Tooth morphology and prey preference of Mesozoic marine reptiles. Journal of Vertebrate Paleontology 7: 121-137.

Massare, J.A., 1997. Faunas, behaviour, and evolution. Introduction. In: Callaway, J.M. \& Nicholls, E.L. (eds): Ancient Marine Reptiles. Academic Press (San Diego): 401-421.

Meijer, A.W.F., 1982. Over de wenselijkheid om Carinodens belgicus (Woodward, 1892) (Reptilia, Mosasauridae) van de faunalijst van de Limburgse Krijtafzettingen af te voeren. Natuurhistorisch Maandblad 71: 215-216.

Metzger, K., 2002. Cranial Kinesis in Lepidosaurs: Skulls in Motion. In: Aerts, P., D'Août, K., Herrel, A. \& Van Damme, R. (eds): Topics in Functional and Ecological Vertebrate Morphology. Shaker Publishing (Maastricht): 15-46.

Mulder, E.W.A., 2003. Comparative osteology, palaeoecology and systematics of the Late Cretaceous turtle Allopleuron hofmanni (Gray 1831) from the Maastrichtian type area. In: Mulder, E.W.A., 2003: On latest Cretaceous tetrapods from the Maastrichtian type area. Publicaties van het Natuurhistorisch Genootschap in Limburg 46(1): 23-92.

Peyer, B., 1929. Das Gebiss von Varanus niloticus L. und von Dracaena guianensis Daud. Revue Suisse de Zoologie 36: 71-102.

Price, L.I., 1957. A presença de Globidens no Cretácico superior do Brasil. Boletim da Divisão de Geologia e Mineralogia 169: 1-24.

Rayfield, E.J., Norman, D.B., Horner, C.C., Horner, J.R., Smith, P.M., Thomason, J.J. \& Upchurch, P., 2001. Cranial design and function in a large theropod dinosaur. Nature 409: 1033-1037.

Russell, D.A., 1964. Intracranial mobility in mosasaurs. Postilla 86: 1-19.

Russell, D.A., 1967. Systematics and Morphology of American Mosasaurs. Bulletin of the Peabody Museum of Natural History, Yale University 23: $241 \mathrm{pp}$.

Russell, D.A., 1975. A New Species of Globidens from South Dakota, and a Review of Globidentine Mosasaurs. Fieldiana 33: 235-256.

Schulp, A.S., Jagt, J.W.M. \& Fonken, F., 2004. New material of the mosasaur Carinodens belgicus from the Upper Cretaceous of The Netherlands. Journal of Vertebrate Paleontology 24: 744-747.

Sinclair, A.G. \& Alexander, R.MCN., 1987. Estimates of forces exerted by the jaw muscles of some reptiles. Journal of Zoology 213: 107-115.

Therrien, F., Henderson, D.M. \& Ruff, C.B., 2003. Biomechanical models of theropod mandibles and implications for feeding behavior. Journal of Vertebrate Paleontology 23 (suppl. to 3): 103.

Therrien, F., Henderson, D.M. \& Ruff, C.B., in press. Bite me: Biomechanical models of theropod mandibles and implications for feeding behavior. In: Carpenter, K. (ed.): The Carnivorous Dinosaurs. Indiana University Press, Bloomington.

Tzankov, V., 1939. Note sur la présence des reptiles fossiles du Crétacé supérieur de la Bulgarie du Nord. Geologica Balkanica 3: 13-20.
Vonhof, H.B. \& Smit, J., 1996. Strontium-isotope stratigraphy of the type Maastrichtian and the Cretaceous/Tertiary boundary in the Maastricht area (SE Netherlands). In: Brinkhuis, H. \& Smit, J. (eds): The Geulhemmerberg Cretaceous/Tertiary boundary section (Maastrichtian type area, SE Netherlands). Geologie en Mijnbouw 75: 275-282.

Williston, S.W., 1898. Mosasaurs. The University Geological Survey of Kansas 4: 83-221.

Williston, S.W., 1914. Water reptiles of the past and present. Chicago University Press (Chicago): $251 \mathrm{pp}$.

\section{Institutional abbreviations}

IRScNB - Institut Royal des Sciences Naturelles de Belgique, Brussels, Belgium. NHMM - Natuurhistorisch Museum Maastricht, Maastricht, the Netherlands. PR - Field Museum of Natural History, Chicago, IL, USA. 